\title{
Effect of plant-biostimulant on cassava initial growth
}

\author{
João Emílio de Souza Magalhães ${ }^{1}$, Evander Alves Ferreira ${ }^{2}$, Maxwel Coura de Oliveira ${ }^{3}$, Gustavo Antonio Mendes \\ Pereira $^{4}$, Daniel Valadão Silva ${ }^{5}$ José Barbosa dos Santos ${ }^{6}$
}

$10.1590 / 0034-737 X 201663020012$

\begin{abstract}
Biostimulants are complex substances that promote hormonal balance in plants, favor the genetic potential expression, and enhance growth of shoots and root system. The use of these plant growth promoters in crops can increase quantitatively and qualitatively crop production. Therefore, the aim of this study was to evaluate the effect of a commercial biostimulant on the initial growth of cassava. The experiment was arranged in a 2 x 5 factorial design, corresponding to two cassava cultivars (Cacau-UFV and Coimbra) and five biostimulant concentrations ( $0,4,8,12$ and $\left.16 \mathrm{~mL} \mathrm{~L}^{-1}\right)$. At 90 days after planting, the characteristics leaf area, plant height, stem diameter, leaf number, total dry matter and dry matter of roots, stems and leaves were evaluated. The biostimulant promoted linear increases in plant height, leaf number, leaf area, total dry matter, dry matter of stems, leaves and roots. The cultivar Cacau-UFV had a higher growth rate than the cultivar Coimbra. The growth promoter stimulated the early growth of the cassava crop.
\end{abstract}

Key words: roots, plant hormones, Manihot esculenta Crantz.

\section{RESUMO}

\section{Crescimento inicial da mandioca sob efeito de bioestimulante vegetal}

Os bioestimulantes são complexos que promovem o equilíbrio hormonal das plantas, favorecendo a expressão do seu potencial genético, estimulando o crescimento da parte aérea e do sistema radicular. O uso desses reguladores vegetais em cultivos agrícolas pode causar aumentos quantitativos e qualitativos da produção das culturas. Diante disso, o objetivo deste estudo foi avaliar o efeito de bioestimulante comercial no crescimento inicial da mandioca. Adotou-se esquema fatorial 2 × 5, correspondente a duas cultivares de mandioca (Cacau-UFV e Coimbra) e a cinco concentrações do bioestimulante $\left(0,4,8,12\right.$ e $\left.16 \mathrm{~mL} \mathrm{~L}^{-1}\right)$. Aos 90 dias após o plantio, avaliaram-se área foliar, altura da planta, diâmetro do caule, número de folhas e as matérias secas de raízes, caule, folhas e total. O bioestimulante promoveu incrementos lineares da altura de planta, do número de folhas, da área foliar, das matérias secas de caule, folhas, raízes e total. A cultivar Cacau-UFV apresentou maior crescimento que a cultivar Coimbra. O uso do bioestimulante na cultura da mandioca estimula o crescimento inicial da cultura.

Palavras-chave: enraizamento, hormônios vegetais, Manihot esculenta Crantz.

\footnotetext{
Submitted on 03/31/2014 and approved on 11/10/2015.

${ }^{1}$ Universidade Federal do Jequitinhonha e Mucuri, Departamento de Agronomia, Diamantina, Minas Gerais, Brasil. jonemilho@yahoo.com.br

${ }^{2}$ Universidade Federal do Jequitinhonha e Mucuri, Departamento de Agronomia, Diamantina, Minas Gerais, Brasil. evanderalves@yahoo.com.br

${ }^{3}$ Universidade Federal do Jequitinhonha e Mucuri, Departamento de Agronomia, Diamantina, Minas Gerais, Brasil. maxwelco@gmail.com

${ }^{4}$ Universidade Federal de Viçosa, Departamento de Fitotecnia, Viçosa, Minas Gerais, Brasil. gustavogamp@hotmail.com

${ }^{5}$ Universidade Federal de Viçosa, Departamento de Fitotecnia, Viçosa, Minas Gerais, Brasil. danielvaladaos@yahoo.com.br

${ }^{6}$ Universidade Federal do Jequitinhonha e Mucuri, Departamento de Agronomia, Diamantina, Minas Gerais, Brasil. jbarbosasantos@yahoo.com.br

*Corresponding author: danielvaladaos@yahoo.com.br
} 


\section{INTRODUCTION}

Cassava is one of the major crops grown in Brazil. Cassava roots have a high capacity to store starch, which is the reason they are the organs of the plant with the greatest economic value. Despite its importance to the country, management strategies to ensure higher crop yields have been little studied (Silveira et al., 2012).

The use of plant growth regulators or bioregulators in agriculture has been a means of promoting quantitative and qualitative increases in crop production, as when these substances are applied directly to the plants, they promote changes in vital and structural processes, increasing sucrose content, early ripening and crop yields (Martin \& Castro, 1999; Caputo et al., 2007). Because of the benefits these substances bring to cultivated plants, combinations of these products have also been studied. These mixtures are called plant stimulants or biostimulants, and are effective when applied in small doses, favoring the growth and development of the plant even under adverse environmental conditions (Casillas et al., 1986).

The commercial biostimulant contains $0.005 \%$ IBA (auxin), $0.009 \%$ kinetin (cytokinin) and $0.005 \%$ gibberellic acid (gibberellin) in its basic composition (Castro et al., 1998). Some of the benefits of biostimulants include: increase in plant growth rate, which is stimulated by cell division, differentiation and elongation. Contradictory results about the application of the biostimulant are reported in the literature. While biostimulant increased growth and productivity of soybean and blackberry (Vieira, 2001; Ferreira et al., 2007a), other authors reported no significant changes in sweet potatoes, soybeans and corn (Dario et al., 2005; Ferreira et al., 2007b; Rós et al., 2015). This variation has been attributed to different application times, doses applied and genotypes.

Information about the use of biostimulant in cassava is still scarce. Therefore, the objective of this research was to evaluate the effects of different doses of the biostimulant on the initial growth of two cassava cultivars.

\section{MATERIALAND METHODS}

The experiment was conducted in a protected environment. A medium textured Red-Yellow Latosol (typical) was used as substrate. The soil properties were: $\mathrm{pH}$ (water) 5.4; organic matter content $1.6 \mathrm{dag} \mathrm{kg}^{-1}$; P, K and $\mathrm{Ca}$ at $0.25 ; 164.9$ and $1.60 \mathrm{mg} \mathrm{dm}^{-3}$, respectively; $\mathrm{Mg}$, $\mathrm{Al}, \mathrm{H}+\mathrm{Al}$ and effective cation exchange capacity (ECEC) at $1.10 ; 0.04 ; 3.0$ and $3.16 \mathrm{cmol}_{\mathrm{c}} \mathrm{dm}^{-3}$, respectively. The substrate was amended with $300 \mathrm{~g}$ of ammonium sulfate, $250 \mathrm{~g}$ of potassium chloride, and $5000 \mathrm{~g}$ single superphosphate per $\mathrm{m}^{3}$ of soil (Walnut \& Gomes, 1999).

The experiment was arranged in a randomized complete block design with four replications. Each 10-L pot filled with substrate represented an experimental unit. A 2 x 5 factorial arrangement was used, corresponding to two cassava cultivars (Cacau - UFV and Coimbra) and five concentrations of biostimulant $\left(0,4,8,12\right.$ and $\left.16 \mathrm{~mL} \mathrm{~L}^{-1}\right)$.

The commercial biostimulant contained $0.09 \mathrm{~g} \mathrm{~L}^{-1}$ kinetin, $0.05 \mathrm{~g} \mathrm{~L}^{-1}$ gibberellic acid, $0.05 \mathrm{~g} \mathrm{~L}^{-1}$ indole - butyric acid, and $999.8 \mathrm{~g} \mathrm{~L}^{-1}$ of inert ingredients. Planting was carried out in April 2011, using an automatic sprinkler irrigation system. Cassava cuttings of approximately $10 \mathrm{~cm}$ long, with two gems, were immersed in a solution of biostimulant diluted in distilled water for 1 minute and immediately planted in the pots, two cuttings per pot, in a horizontal position. The biostimulant doses were calculated according to use recommendations, along with the control, which was immersed in distilled water only for 1 minute, to make factors equal, totalizing five doses.

At 90 days after planting, leaf area, plant height, stem diameter, root volume and leaf number were evaluated. Leaf area was determined by separating the leaves of all plants, scanning and digitizing with the software Digital Area Determinator (DAD). Subsequently, the plant material was washed in distilled water and dried in a forced-aircirculation oven at $70^{\circ} \mathrm{C}$ to constant weight. Determination of dry matter was carried out on an electronic scale accurate to $0.001 \mathrm{~g}$. These data were used to determine the fresh and dry matter of vegetative components of cassava.

The analysis of variance confirmed the interaction between the factors cassava cultivar and biostimulant dose. Means of the quality factor (cultivars) were compared by the $t$ test $(\mathrm{p}<0.05)$ and the means of the quantitative factor (doses) were subjected to regression analysis. The choice of linear model was based on the significance of the coefficients $(p<0.05)$, the coefficient of determination and the biological phenomenon observed in the experiments.

\section{RESULTS AND DISCUSSION}

Plant height of the two cassava cultivars increased linearly with the biostimulant dose (Figures 1a and 1b). Cultivar Coimbra was always higher than cultivar CacauUFV, which can be attributed to growth differences between the genotypes, agreeing with findings of other studies (Silva et al., 2011; Silveira et al., 2012.).

Increase in stem diameter (SD) with the biostimulant dose was similar for the two cassava cultivars (Figure 1b). This may be related to the gibberellins, which is one of the biostimulant components. Gibberellins increase cell division and cell elongation, which becomes evident with the increased length and number of cells. The greater initial growth of biostimulant-treated plants results from the elongation of the intercalary meristem cells, whose increase in size promotes cell division (Sauter \& Kende, 1992). Thus, 
the highest increases in $\mathrm{H}$ observed in this study were probably caused by the increased number of new cells and the increased cell elongation in response to gibberellin (Sauter \& Kende, 1992), without, however, affecting plant SD.

The leaf number (LN) increased linearly with biostimulant for cultivar Cacau-UFV, whereas there was no significant effect for cultivar Coimbra (Figure 1c). However, both cultivars increased the leaf area (LA), but the increase for Cacau-UFV was higher (Figure 1d). Opposite to that observed for $\mathrm{H}$, cultivar Cacau-UFV had LA 69\% greater than cv. Coimbra, without biostimulant application. LA had increments of 25 and $31 \%$ for CacauUFV and Coimbra, respectively, with the application of the highest biostimulant dose.

Despite having smaller LN and greater LA than cv. Coimbra, cv. Cacau-UFV was more responsive to
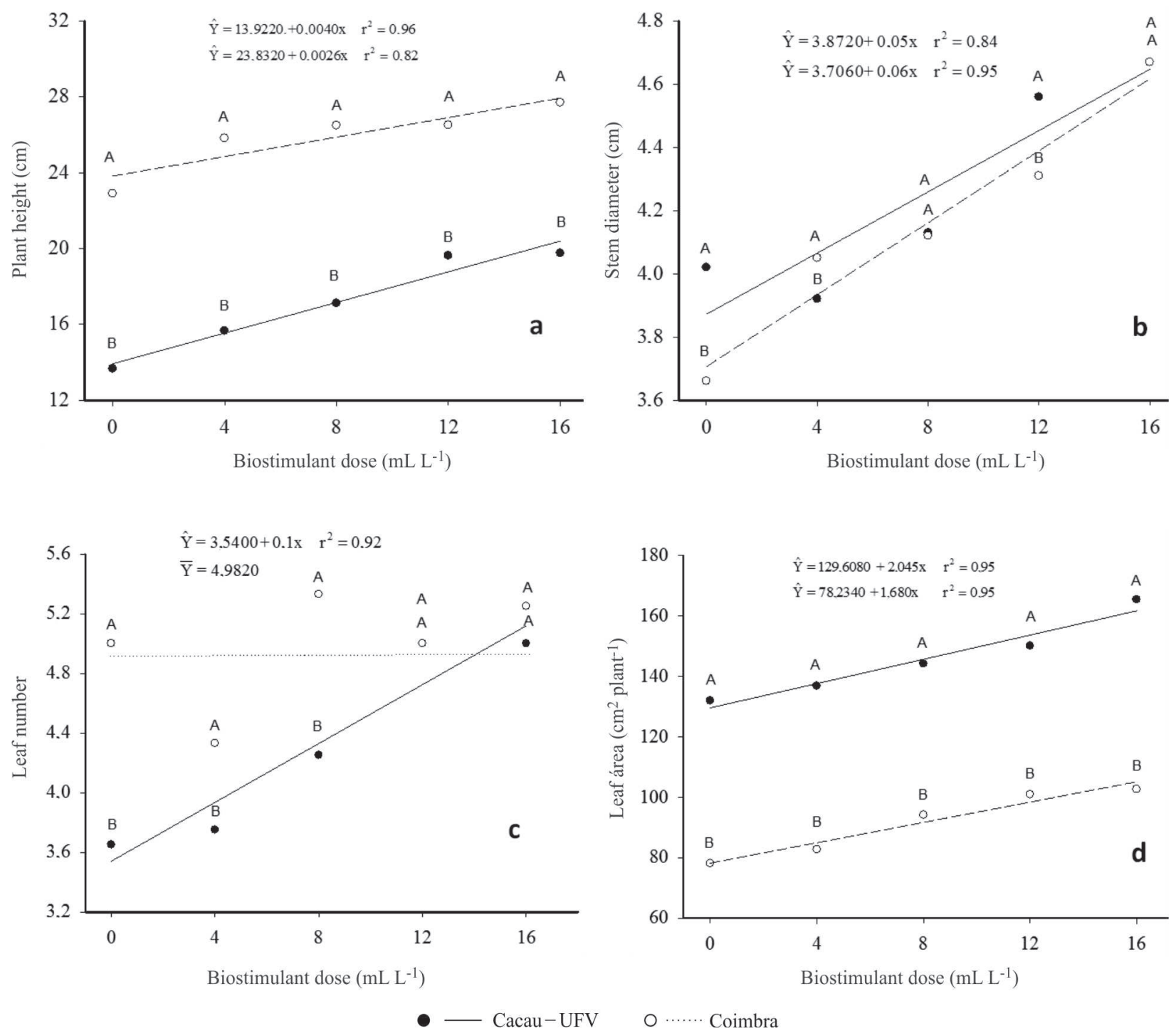

- Cacau-UFV

biostimulant application, having LN means similar to the other cultivar (Figure 1). Increased LN and LA is desirable because the cassava plant will have a greater photosynthetic active area, with greater contributions to productivity gains, as well as increasing the soil cover and possibly reducing the interference of weeds (Silva et al., 2012).

Cultivar Cacau-UFV showed a linear increase of root volume (RV) with increasing biostimulant doses. However, this trend was not observed in cv. Coimbra (Figure 2a). According to Connor et al., (1981), doses between 700 and $820 \mathrm{~mL} \mathrm{ha}^{-1}$ of biostimulant promoted positive effects on the early development of the cassava root system. Feltran et al., (2009) found that doses between 700 and 820 $\mathrm{mL} \mathrm{ha} \mathrm{h}^{-1}$ of biostimulant promoted positive effects on the early development of the root system of IAC 14, especially with increases in length and surface. A more vigorous root

Figure 1: Height (a), stem diameter (b), leaf number (c) and leaf area (d) per plant of two cassava cultivars as a function of biostimulant doses.

Rev. Ceres, Viçosa, v. 63, n.2, p. 208-213, mar/abr, 2016 
development can promote the absorption, mainly of water, at the beginning of the crop establishment, which is essential for the survival of most plants in the field and to lower the number of failures in the plant stand.

Reghin et al., (2000) found significant effect of increasing doses of biostimulant on the number and length of roots of peruvian carrot (Arracacia xanthorriza Bancroft) up to the limit of $7.0 \mathrm{~mL} \mathrm{~L}^{-1}$, indicating that it enhances growth and root development. Peressin \& Carvalho (2002) reported that, from 7 to 90 days after planting the cassava cuttings, the phase of root system formation starts, especially the fibrous roots, with some of these turning into storage roots later. Thus, the increments of dry mass become important for producing higher yields of roots.

Figure $2 \mathrm{~b}$ shows that there are linear increases in shoot dry matter (SDM) for cv. Cacau-UFV and cv. Coimbra. The responses of the two cultivars to the biostimulant were similar, as the slope of the fitted regression equations shows. Although there is no increase in stem diameter (SD) (Figure 1b), the increase in stem dry matter (SDM) was due to increased height $(\mathrm{H})$ (Figure 1a), because of the biostimulant. This is a desirable characteristic, since cassava propagates vegetatively via cuttings, thus, any positive or negative stimulus to shoot growth in early development may affect directly the quality of the planting material and production in subsequent crops. Silva et al., (2010), testing a biostimulant in sugarcane, observed increased yield in sugarcane ratoon, irrespective of genotype, with or without supplementation of liquid fertilizer, which indicated the possibility of increasing longevity of sugarcane plantations. Vieira \& Santos (2005) reported increased dry matter of roots, shoots and whole plants, as well as the vertical root growth speed, vertical
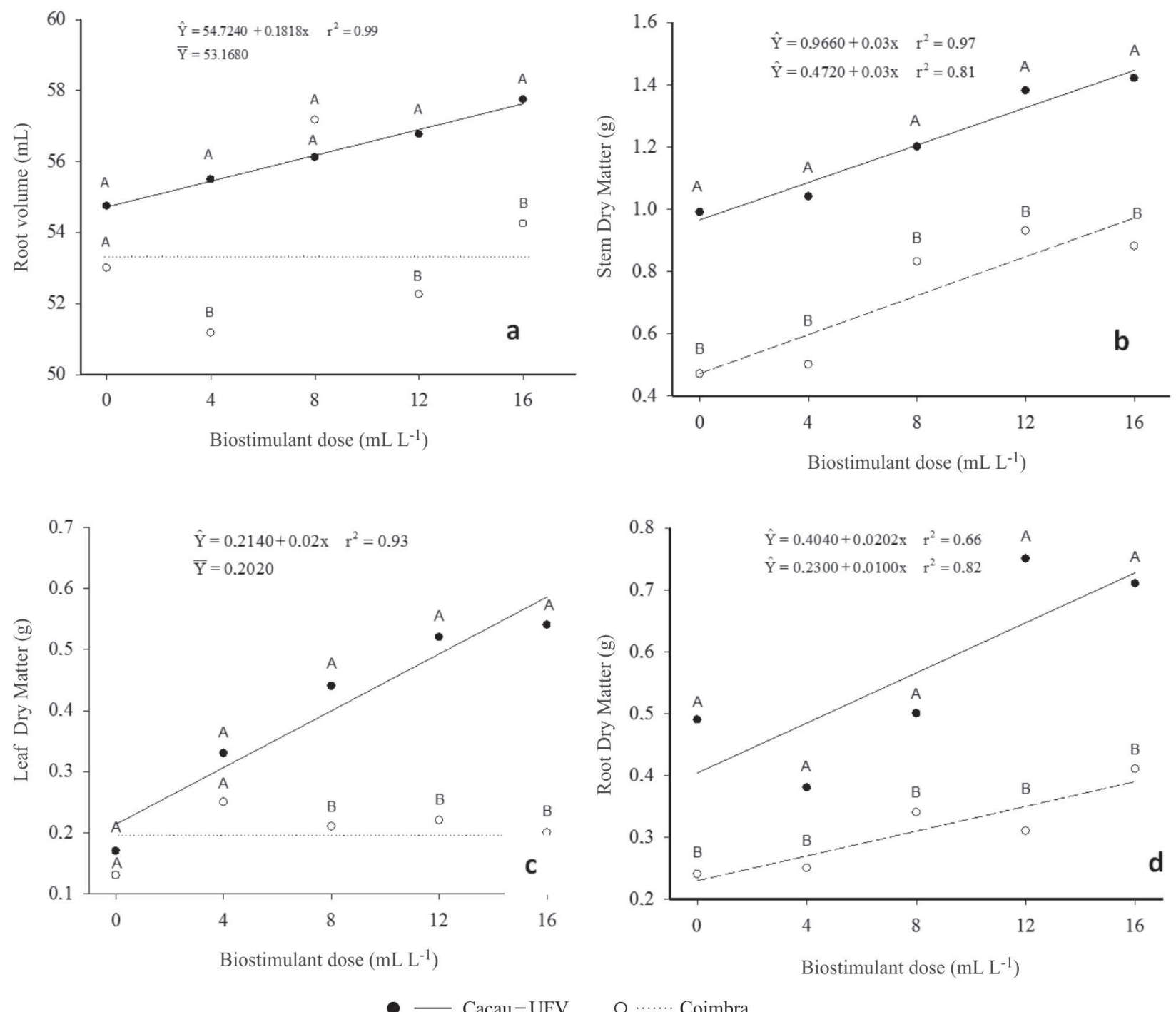

Figure 2: Root volume (a) stem dry matter (b), leaf dry matter (c) and root dry matter (d) per plant of two cassava cultivars as a function of biostimulant doses. 
root growth rate and vertical root growth of cotton, with the application of the product.

Cultivar Cacau-UFV showed linear increases in leaf dry matter (LDM), while cv. Coimbra did not respond to the biostimulant application (Figure 1c). It was found increased LDM, approximately $150 \%$, for Cacau-UFV, at the highest dose.

The root dry matter (RDM) of cassava cultivars increased linearly in the presence of the biostimulant (Figure 2d). Cultivar Cacau-UFV had higher RDM than cv. Coimbra for all doses evaluated. Gibberellins (one of the components of the biostimulat applied to the cuttings) have a stimulating effect on the germination when applied to seeds or plant parts intended for vegetative propagation such as cassava cuttings. Seeds or cuttings may require gibberellins to a series of events: activation of sprouting, callus formation, activation of the vegetative growth of gems and mobilization of reserves, which favors growth (Taiz \& Zeiger, 1998). Silva et al., (2012) discuss that the formation of cassava root system starts on the seventh day after planting, and between the second and third months occurs the differentiation of roots that will be the starch reserve of the others. Thus, the increased root growth in the initial phase of development becomes important to increase the production of roots that are part of the commercial plant.

The two cultivars showed linear increases of the mass of total dry matter (TDM), but Cacau-UFV was twice more responsive to the biostimulant than Coimbra (Figure 3). While the increase for Coimbra is a function of the response to SDM, Cacau-UFV has increases in SDM and the LDM, i.e., the highest response for this cultivar is in terms of area. These results suggest that the biostimulant enables greater growth of cassava mainly by stimulating the shoot formation .

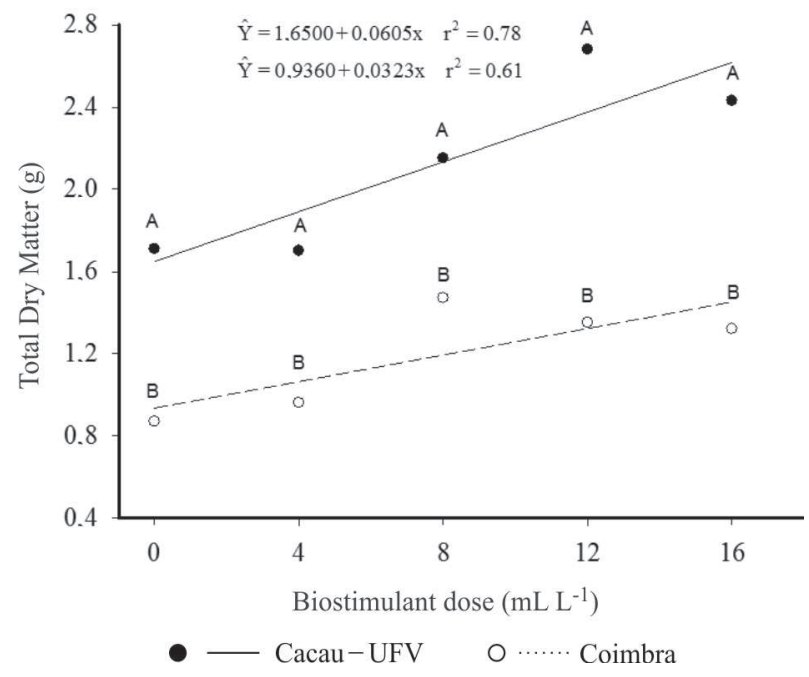

Figure 3: Total dry matter per plant of two cassava cultivars after the application of different doses of biostimulant.
Cultivar Cacau-UFV showed higher growth than cv. Coimbra due to the biostimulant application. These results suggest that the response to the product varies according to the genotype, and that the dose used should be adjusted for each genetic material. Considering the fit of the linear model, it is recommended to evaluate larger doses of the biostimulant. Moreover, field studies are recommended to evaluate the effective biostimulant response in the production of cassava tuberous roots, since the initial growth of the crop is stimulated by biostimulant application to the cuttings before planting.

\section{CONCLUSIONS}

The application of biostimulant promotes greater early growth of cassava.

The response to biostimulant depends on the cassava cultivar.

The biostimulant application caused a greater growth increase in cultivar Cacau-UFV than in cultivar Coimbra.

\section{REFERENCES}

Caputo MM, Silva MA, Beauclair EGF \& Gava GJC (2007) Acúmulo de sacarose, produtividade e florescimento de cana-de-açúcar sob reguladores vegetais. Interciência, 32:834-840.

Casillas VJC, Londoño IJ, Guerrero AH \& Buitrago GL (1986) Análisis cuantitativo de la aplicación de cuatro bioestimulantes en el cultivo del rabano (Raphanus sativus L.). Acta Agronomica, 36:185-195.

Castro PRC, Pacheco AC \& Medina CL (1998) Efeitos de Stimulate $^{\circledR}$ e de micro-citros no desenvolvimento vegetativo e na produtividade da laranjeira 'Pêra' (Citrus sinensis L. Osbeck). Scientia Agricola, 55:338-341.

Connor DJ, Cock JH \& Parra GE (1981) Response of cassava to water shortage. I. Growth and yield. Field Crops Research, 4:181-200.

Dario GJA, Martin TN, Dourado Neto D Manfron PA, Bonnecarrère RAG \& Crespo Pen (2005) Influência do uso de fitorregulador no crescimento da soja. Revista da Faculdade de Zootecnia, Veterinária e Agronomia, 12:63-70.

Feltran JC, Valle TL \& Galera JMSV (2009) Efeito de bioestimulante (Stimulate ${ }^{\circledR}$ ) no desenvolvimento radicular da mandioca de indústria variedade IAC-14. In: XIII Congresso Brasileiro de Mandioca, Botucatu. Anais, Unesp. p.1-3.

Ferreira G, Costa PN, Ferrari TB, Rodrigues JD, Braga JF \& Jesus FA (2007a) Emergência e desenvolvimento de plântulas de maracujazeiro azedo oriundas de sementes tratadas com bioestimulante. Revista Brasileira de Fruticultura, 29:595-599.

Ferreira LA, Oliveira JA, Von Pinho EVR \& Queiroz DL (2007b) Bioestimulante e fertilizante associados ao tratamento de sementes de milho. Revista Brasileira de Sementes, 29:80-89.

Nogueira FD \& Gomes JC (1999) Mandioca. In: Ribeiro AC, Guimarães PTG \& Alvarez Viegas VH (Eds.) Recomendações para o uso de corretivos e fertilizantes em Minas Gerais: $5^{\text {a }}$ aproximação. Viçosa, Comissão de Fertilidade do Solo do Estado de Minas Gerais. p.312-313.

Martins MBG \& Castro PRC (1999) Efeito de giberelina e ethephon na anatomia de plantas de cana-de-açúcar. Pesquisa Agropecuária Brasileira, 34:1855-1863. 
Peressin VA \& Carvalho JEB (2002) Manejo Integrado de plantas daninhas em mandioca. In: Cereda MP (Ed.) Cultura de Tuberosas Amiláceas Latino Americanas. São Paulo, Fundação Cargill. p.302-349.

Reghin MY, Otto RF \& Silva JBC (2000) "Stimulate ${ }^{\circledR}$ Mo" e proteção com tecido "não tecido" no pré-enraizamento de mudas de mandioquinha-salsa. Horticultura Brasileira, 18:53-56.

Rós AB, Narita N \& Araújo HS (2015) Efeito de bioestimulante no crescimento inicial e na produtividade de plantas de batatadoce. Revista Ceres, 62:469-474.

Sauter M \& Kende H (1992) Gibberellin-induced growth and regulation of the cell division cycle in deepwater rice. Planta, 188:362-368.

Silva DV, Santos JB, Silveira HM, Carvalho FP, Castro NETO MD, Ferreira EA, Silva AA \& Cecon PR (2011) Tolerância de cultivares de mandioca aos herbicidas fomesafen e fluazifop. Revista Brasileira de Herbicidas, 10:219-231.

Silva DV, Santos JB, Ferreira EA, França AC, Silva AA \& Sediyama $\mathrm{T}$ (2012) Manejo de plantas daninhas na cultura da mandioca. Planta Daninha, 30:901-910.
Silva MA, Cato SC \& Costa AGF (2010) Produtividade e qualidade tecnológica da soqueira de cana-de-açúcar submetida à aplicação de biorregulador e fertilizantes líquidos. Ciência Rural, 40:774-780

Silveira HM, Silva DV, Carvalho FP, Castro Neto MD, Silva AA \& Sediyama T (2012) Características fotossintéticas de cultivares de mandioca tratadas com fluazifop-p-butyl e fomesafen. Revista Agro@mbiente On-line,6:222-227.

Taiz L \& Zeiger E (1998) Plant physiology. $2^{\text {a }}$ ed. Sunderland, Sinauer Associates. 792p.

Vieira EL (2001) Ação de bioestimulante na germinação de sementes, vigor de plântulas, crescimento radicular e produtividade de soja (Glycine max (L.) Merril), feijoeiro (Phaseolus vulgaris L.) e o arroz (Oriza sativa L.). Tese de Doutorado. Escola Superior de Agricultura "Luiz de Queiroz", Piracicaba. $122 \mathrm{p}$.

Vieira LV \& Santos CMG (2005) Estimulante vegetal no crescimento e desenvolvimento inicial do sistema radicular do algodoeiro em rizotrons. In: V Congresso Brasileiro de Algodão, Salvador. Anais, EMBRAPA/CNPA. p.1-3. 